\title{
Değiş Tokuş ve Kiralama Uygulamalarının Konaklama İşletmeleri Üzerindeki Olası Etkileri
}

The Potential Effects of Exchange and Rental Applications on the Hospitality Industry

\author{
Dilek DEMiRER*, Azize HASSAN** \\ * Yüksek lisans öğrencisi, Düzce Üniversitesi, Sosyal Bilimler Enstitüsü, Konuralp Yerleşkesi, 81620, Düzce. \\ E-posta: dilek.demirer@hotmail.com \\ ** Prof. Dr., Gazi Üniversitesi, Turizm Fakültesi, 06830, Gölbaşı, Ankara. \\ E-posta: azize@gazi.edu.tr
}

MAKALE BILGILERI

Makale işlem bilgileri:

Gönderilme tarihi: 26 Mayıs 2015

Birinci düzeltme: 28 Temmuz 2015

İkinci düzeltme: 28 A ̆̆ustos 2015

Kabul: 31 A ̆̆ustos 2015

Anahtar sözcükler:

Paylaşım ekonomisi, Değiş̧ tokuş, Günlük ev kiralama,

Konaklama işletmeleri.

\section{ARTICLE INFO}

Article history:

Submitted: 26 May 2015

Resubmitted: 28 July 2015

Resubmitted: 28 August 2015

Accepted: 31 August 2015

Key words:

Sharing economy,

Exchange, Daily home rental,

Hospitality industry.

\begin{abstract}
ÖZ
Bu araştırma, resmi olmayan konaklama sektöründeki değiş tokuş ve günlük kiralık ev trendinin, geleneksel konaklama sektörü üzerinde etkisinin olup olmadığııı ortaya koymayı amaçlamaktadır. "Paylașım ekonomisi" kavramının ele alındığı araştırmada, değiş tokuş ve kiralama uygulamaları sunan altı web sitesinin; amaçlarına, kullanıcılarına ne tür hizmetler sunduklarına, ne kadar kişi tarafından kullanıldıklarına, tercih nedenlerine, nasıl güven verdiklerine ve risklerine ilișkin bilgiler sorgulanmıștır. Araștırma bu yönüyle keşifseldir ve elde edilen veriler nitel karakterler taşımaktadır. Araştırmanın yöntem kısmında veri toplama aracı olarak doküman incelemesi yöntemi kullanılmış, elde edilen bulgular içerik analizi ile çözümlenmiştir. Araştırma sonucunda ise alternatif konaklama olanağı sunan bu sitelerin, genel olarak maliyet tasarrufu sağlayarak ev rahatlığında tatil yapmak için, macera/eğlence amaçlı seyahat eden kișiler tarafından tercih edildiği ortaya çıkmıștır. Değiș tokuş ve kiralama hizmeti sunan bu siteler, her ne kadar alanyazında "yıkıcı yenilik" olarak adlandırılsa da incelenen sitelerin konaklama işletmeleri karşısında şu an sınırlı bir tehdit oluşturdukları ve bu halleriyle bir niş pazar konumunda oldukları söylenebilir.
\end{abstract}

\section{GíRiş}

İnternet, geliştirildiği günden beri insanların yaşamında büyük bir yer kaplamış ve başta sosyal ağlar olmak üzere içinde barındırdığ 1 çok çeşitli sistemlerle hem enformasyon ve bilginin çok hız11 bir şekilde yayılmasına hem de paylaşım kavramını dönüştürerek insanların karşılıklı paylaşımlar yapabilmesine olanak sağlamıştır. Bu paylaşımların yeni bir türü de Rachel Botsman ve Roo Rogers' in (2010) 'Benim Olan Senindir' (What's Mine is Yours) isimli kitaplarında "ortak kullanım ağları" olarak adlandırdıkları mal ve hizmetlerin kiralanmasını ya da paralı veya parasız takas edilmesini sağlayan sistemlerdir.

Sosyal ağlar kişiler arası etkileşimin şeklini değiştirirken, 2000'li yıllarda geliştirilen bu sistemler kullanım, erişim ve paylaşımı destekleyerek tüketime alternatif bir seçenek olmaya başlamışlardır. Ortak kullanım ağları, iletişimi çevrimiçinden çevrimdışına taşımayı amaçlayan, insanları günlük hayatla buluşturan sitelerdir. Facebook, Twitter gibi sosyal ağlarda, duygu ve düşünceler 
değiş tokuş içindeyken bu sitelerde insanlar yüz yüze gelip eşya ya da bilgilerini paylaşmaktadır.

Time dergisinin dünyayı değiştirecek 10 büyük fikirden biri olarak gördüğü ortak kullanım ağları, genelde daha az tüketmek ve daha az para harcamak amaciyla oluşturulmuştur (Walsh 2011). Bu anlayışla günümüz tüketicileri bir şeye sahip olmak yerine, onu ödünç almayı ya da kiralamayı tercih etmektedir. Böylece "paylaşım ekonomisi" denen eğilimin bir parçası olan daire/villa kiralama ya da yazlığını başka bir ülkede bulunan bir diğeriyle değiştirme günümüz seyahat trendleri arasında yerini almıştır.

Mal ve hizmetlerin takas edilmesi ticaretin en eski halidir (World Economic Forum 2013). Tarih boyunca kasabalar, şehirler ve kırsal kesimlerde ikinci el takas pazarları kurulmuştur. Ancak bu pazarlar az sayıda insana ulaşmış daha çok yerel ölçekte hizmet vermiştir. Yaklaşık 15 yıl önce ise "kişiden kişiye ticaret" (P2P) olarak adlandırılan bir sistemle, alışveriş şekli yerellikten küreselliğe adım atmış ve daha fazla insana ulaşma olanağ 1 sağlanmıştır. Gittikçe gelişen bu sistem günümüzde turizm sektörü içerisinde de kendine yer bulmuş ve "kişiden kişiye seyahat" kavramına dönüşmüştür. Kişiden kişiye seyahat; seyahatte birinin evinde misafir olma, evini bir başkasıyla değiştirerek seyahat etme veya oda kiralama gibi hizmetler sunan web siteleri aracıllğıyla sağlanmaktadır.

Bu çalışma ise ev değiş tokuşu ve günlük kiralık ev yani kişiden kişiye seyahat olanağı sunan web sitelerinin geleneksel konaklama işletmeleri üzerinde nasıl etkileri olduğunu ortaya çıkarmayı amaçlamıştır. Alanyazın incelemesinde, Türkiye'de turizmde "değiş tokuş ve kiralama" uygulamalarının etkisi adı altında bir çalışmaya rastlanmamıştır. Bu durum da araştırmanının alana katkı sağlaması açısından özgün bir değer oluşturmaktadır.

\section{KAVRAMSAL ÇERÇEVE}

\section{Paylaşım Ekonomisi}

Zamanla değişen ekonomik şartların ve gelişen internet teknolojisinin sonucunda oluşmaya başlayan bir kavram olan paylaşım ekonomi- si; insanların bir araya gelip kendi pazarlarını (Airbnb), kendi ürünlerini (Etsy) ve kendi para birimlerini (TimeBanks) yaratmalarına dayanmaktadır. Paylaşım ekonomisinde aslında hiçbir şey ücretsiz değildir, satın almak yerine ödünç almak anlayışına dayanır. Böylece kişi kendi ekonomisine katkı sağlarken sosyal bir deneyim de yaşamış olur ki, günümüzde bireylerin de organizasyonların da markaların da en çok peşinde koştuğu şey, deneyim yaratmaktır.

Genel anlamda, paylaşım ekonomisi fikri, fırınlarda uygulanan 'askıda ekmek' ve kafelerde uygulanan 'askıda kahve' geleneğine benzemektedir. Bu sistem, olanağı olan kişilerin ihtiyacı olanlar için satın aldığı ekmek ya da kahve için, işletme duvarındaki askıya fiş koyması ve ihtiyacı olan kişilerin de gelip askıda olan fişlerle kahve ya da ekmeğini almasına dayanır.

Paylaşım ekonomisinin gelişiminde üç faktör etkili olmuştur. Bunlar; sosyal, ekonomik ve teknolojik faktörlerdir (Finley 2013). Dünya nüfusunun gün geçtikçe artmaya devam etmesi, yaşlı insanların günümüzde daha uzun bir hayat yaşaması (World Economic Forum 2013) doğal kaynakların şu an yedi milyar kişi tarafından tüketilmesine neden olmaktadır. Gansky (2010: 28) bu durumu "Sürdürülebilir bir dünya istiyorsak elimizdeki kaynakları paylaşmalı, verimli bir şekilde kullanmalıyı." sözleriyle özetleyerek paylaşım ekonomisinin önemine dikkat çekmiştir. Sosyal ağlar ve mobil internet teknolojisi ise paylaşım ekonomisinde sıçrama yaşanmasına neden olmuştur. Ortak kullanım ağları sayesinde daha fazla kişiye daha çabuk bir şekilde erişim sağlanmaktadır.

Rachel Botsman ve Roo Rogers (2010), ortak kullanım ağlarını üç kategoriye ayırmıştır; ürün servis sistemleri, yeniden dağıtım pazarları ve ortaklaşa yaşam tarzları.

Ürün Servis Sistemleri (Product Service Systems): Bir şirket veya kişi tarafından sahip olunan ürünlerin paylaşıldığı ortak kullanım ağlarına ürün servis sistemleri adı verilmektedir. Ürün servis sistemleri genelde bir ürünü sahip olmadan kullanmaya, kiralamaya yani "kullandığın kadar öde" mantığına dayanmaktadır. Ürün servis sistemlerine en yaygın örnekler şunlardır: 
Tablo 1. Ürün Servis Sistemleri

\begin{tabular}{|c|c|}
\hline Araba paylaşımı & $\begin{array}{l}\text { Üç şekilde gerçekleşmektedir: 1) Arabanın başka birine saatlik veya günlük olarak kiralanmasıyla, } \\
\text { 2) Gidilecek güzergâhta başkalarıyla aynı aracı paylaşarak, 3) Ticari şirketler aracılı̆̆ıyla oluşturulmuş } \\
\text { 'araba havuz'larına üye olunarak. Araba paylaşımının; Zipcar, Streetcar, GoGet gibi örnekleri mevcuttur. } \\
\text { Türkiye'de AtlaGit, Mobilizm, BlaBlaCar gibi örnekleri vardır. }\end{array}$ \\
\hline Bisiklet paylaşımı & $\begin{array}{l}\text { Şehirde ortak kullanıma hazır olarak bulunan bisiklet kiralama servisleridir. Bixi, Smartbike gibi örnekleri vardır. } \\
\text { Türkiye'de Baksi bu konuda hizmet vermektedir. }\end{array}$ \\
\hline Sürüş paylaşımı & $\begin{array}{l}\text { Aynı yere gitmekte olan kişilerin araç paylaşımını sağlamaktadır. Insanlar hem tasarruf yapmakta, hem de daha } \\
\text { az tüketmiş olmaktadırlar. Yurtdışında Zimride, Nuride gibi örnekleri bulunmakta, Türkiye'de de Ucuza } \\
\text { Gidelim isimli bir girişim bulunmaktadır. }\end{array}$ \\
\hline Oyuncak paylaşımı & $\begin{array}{l}\text { Oyuncaklar, belki en kısa ömürlü eşyalardandır. Bu nedenle çöpe atılacağına, onları değerlendirebilecek yeni } \\
\text { sahiplerine ulaşabilir. Rent-a-toy, BabyPlays gibi sitelerde oyuncak kiralamak mümkündür. Türkiye'de ise } \\
\text { "Al Oyna Ver" isimli bir oyuncak kiralama sitesi bulunmaktadır. }\end{array}$ \\
\hline Giysi kiralama & $\begin{array}{l}\text { Kleidere, Fashionhire, Bag, Borrow \& Steal, From Bags to Riches, Türkiye'de Davet Çok Elbisem Yok gibi sitelerde } \\
\text { kıyafet, takı, ayakkabı vb. ürünler kiralanmaktadır. }\end{array}$ \\
\hline Film kiralama & En bilinen örneği Netflix'tir. Aylık ödenen bir miktar aidat karşılığı sınırsız film izleme olanağı tanımaktadır. \\
\hline Kişiden kişiye kiralama & $\begin{array}{l}\text { Her tür eşyanın kiralanabildiği sitelerin en meşhuru Fransa'dan Zilok'tur. Ecomodo, HireThings gibi örnekleri } \\
\text { mevcuttur. }\end{array}$ \\
\hline Komşudan kiralama & $\begin{array}{l}\text { Sharesomesugar, Neighborrow, Neighborgoods gibi siteler adından da anlaşılacağı üzere birbirine yakın } \\
\text { yaşayan insanları bir araya getiren ve birbirlerinden eşya kiralamalarını sağlayan sitelerdir. }\end{array}$ \\
\hline
\end{tabular}

Kaynak: Tosuner 2012: 6-7, World Economic Forum 2013:5.

Ürün Servis Sistemleri'nde en popüler alan Araba Paylaşımı'dır. Özellikle Kuzey Amerika'da büyüyen bu sektörde 2010 istatistiklerine göre kullanıcı sayısı giderek artmaktadır. 2001 yılında 500 araç, 9136 kullanıcı varken 2010 yılında bu sayılar 10.405 araç ve 516.100 kullanıcı olarak artış göstermiştir. Büyüyen sektöre, büyük markalar da katılmaya başlamıştır. BMW DriveNow, Volkswagen Quicar isimli araba paylaşım sistemlerini kullanıma açmıştır. Kiralanan her araba, trafikteki araçların \%15 azalmasını sağlamaktadır. Araba paylaşımı kullanıcıları, sahip olduklar1 zamana göre \%31 daha az araba kullanmaktadir (Tosuner 2012).

Yeniden Dağıtım Pazarları (Redistribution Markets): Yeniden dağıtım pazarları, sahip olunan malların başkalarıyla paylaşımı ve ortak kullanımına dayanmaktadır. Bu pazarlarda, mal dönüşümü parayla olduğu kadar parasız da gerçekleşmektedir. Eşyaların dolaşımda olduğu bu sistemler "Bir insanın çöpü, diğerinin hazinesidir" düşüncesine dayanmaktadır. Bu dolaşımın en önemli yararı eşyaların atılmaması, tekrar değerlenip kullanılabilmesidir. Aynı zamanda insanlar artık kullanmadıkları eşyaları satıp para kazanabilmektedirler. En yaygın yeniden dağıtım pazarları örnekleri (Bkz. Tablo 2):
Bu pazarın en popüleri, 1 Mayıs 2003'te Amerika Birleşik Devletleri'nde Deron Beal tarafından kurulmuş olan Freecycle'dır. Dünya üzerindeki pek çok ülke ve şehirde bulunan 4.792 bağımsız grubun ve yedi milyonun üzerinde üyenin oluşturduğu bir ağ olan Freecycle; elinde kullanmadı ̆̆ı eşyaları olanlar ile o eşyalara sahip olmak isteyenleri, tamamen ücretsiz olarak e-mail yolu ile birleştirmeye ve geri dönüşümünü arttırmaya çalışan uluslararası bir projedir. Tüm üyeler eşyalarını burada sunabilir veya aradıkları eşya için istekte bulunabilirler. Ama temel kural sunulan veya aranan her eşyanın ücretsiz olmasıdır (Cevheroğlu 2011).

Ortaklaşa Yaşam Tarzları (Collaborative Lifestyles): Ortak kullanım ağlarında sadece eşyalar paylaşılmamaktadır. Hizmet paylaşımı da gerçekleşmektedir. Birbirine yakın ilgi alanları olan insanlar zaman, alan, beceri ve para paylaşmak ve takas etmek için bir araya gelmektedirler. Bu tür sosyal değiş tokuşa olanak veren ağlar, ortaklaşa yaşam tarzları olarak adlandırılmıştır.

Çeşitli becerilere sahip insanlar, bu becerileri ortak kullanım ağında belirterek, bilgilerini başkalarına aktarabilmektedirler. Ofisini veya stüdyosunu kullanmadığı zamanlarda ihtiyacı olan- 
Tablo 2. Yeniden Dağıtım Pazarları

\begin{tabular}{ll}
\hline Büyük pazar yerleri & İkinci el ürünlerin satıldığı, verildiği eBay ve Craiglist gibi büyük sitelerdir. \\
\hline Armağan değişimleri & $\begin{array}{l}\text { Eşyaların ücretsiz olarak değiş tokuş edildiği ağlardır. Yaklaşık sekiz milyon üyesiyle Freecycle Network en bilinenidir. } \\
\text { Giftflow, Freeconomy gibi örnekleri mevcuttur. }\end{array}$ \\
\hline Kitap takası & Thebookswap, Bookmooch gibi sitelerde kitap değiş tokuşu yapıımaktadır. \\
\hline $\begin{array}{l}\text { Bebek ve çocuk } \\
\text { ürünlerinin takası }\end{array}$ & $\begin{array}{l}\text { Aynı oyuncak gibi çocuk ürünleri de uzun ömürlü değildir. Toyswap, thredUp, Tutumlu Anne gibi sitelerde } \\
\text { bu ürünler değiştirilebilir. }\end{array}$ \\
\hline Giyim takası & $\begin{array}{l}\text { Kıyafet, ayakkabı vb. ürünlerin değiş tokuş edilmesidir. Swap Style ve Clothing Exchange'de bu takaslar } \\
\text { yapılırken Türkiye'de de zaman zaman Giysi Takası etkinlikleri düzenlenmektedir. }\end{array}$ \\
\hline Oyun, kitap, film takası & $\begin{array}{l}\text { Swap veya Netcycler'da insanlar oyun, film, kitap değiş tokuşunu aynı ortamda gerçekleştirebilirler. } \\
\text { Türkiye'de de BookSerf isimli bir kitap kiralama sitesi bulunmaktadır. }\end{array}$ \\
\hline
\end{tabular}

Kaynak: Tosuner 2012: 7, World Economic Forum 2013:5.

lara kiralayabilmektedirler. Para yerine saatlerin geçerli olduğu zaman bankalarında hizmet alıp satabilmektedirler. Hepsi ortaklaşa yaşam tarzı olan bu paylaşım türleri, yüz yüze görüşme ve sosyalleşme açısından diğer sistemlere göre daha aktif olmaktadır. Topluluk oluşturma daha önemlidir. Türkiye'den Zumbara örneği gibi zaman bankaları, Couchsurfing, Hub Culture gibi sosyal alanlar örnek verilebilir (Tosuner 2011). Ortaklaşa yaşam tarzlarına örnek konular (Bkz. Tablo 3):

\section{Yıkıcı Bir Yenilik Olarak Değiş-Tokuş ve Günlük Kiralık Uygulamaları}

Kişiden kişiye seyahat, ilk olarak geleneksel yatak ve kahvaltı (B\&B) modelinde başlamıştır. Black (1985) çalışmasında bu konuyu irdelemiş ve 18 yüzyılda Büyük Tur'a katılan turistlerin özel evlerde kaldığını ortaya çıkarmıştır. Gelişen teknoloji ise bu sistemi elektronik ortama dökmüş ve ortak kullanım ağlarıyla daha fazla kişiye, daha güvenilir yollarla ulaştırmaya başlamıştır.

Turizm sektöründe bir internet girişimciliği örneği olan, ev değiş tokuşu ve günlük kiralamaların yapıldığı web siteleri, alanyazında yıkıcr yenilik olarak adlandırılmaktadır (Christensen ve Raynor 2003). Bu siteler alternatif konaklama sektöründe bir niş pazar yaratmakta ve bunu "büyük bir pasta yapmak" yerine "pastadan bir dilim alarak" gerçekleştirmektedir (Shankland 2013).

Aşağıda, ev değiş tokuşu ve günlük ev kiralama uygulamaları ayrıntılı bir şekilde incelenmiştir:

\section{Ev Değiş-Tokuşu}

Dünyanın farklı yerlerindeki tatilcilerin, ev değiş tokuşu olanağ 1 veren web sitelerine üye olarak istedikleri ülkeden diğer üyelerle evlerini bir süreliğine değiştirip tatil yapabilmesine dayalı bir uygulamadır. İki çeşit değiş̧ tokuş yapılabilmektedir (Özbaran 2012):

1. Ev değiş tokuşu,

2. Konukseverlik değiş tokuşu.

Ev değiş tokuşu yapan kişiler evlerini, dairelerini, apartman katlarını her iki tarafa uygun olan zamanda aralarında takas edebilmektedir. Ancak bu takas işlemi daireyle sınırlı kalmamakta yat, villa, karavan ile de değişim gerçekleşebilmektedir. Ayrıca ev değiş tokuşu esnasında isteyen kişiler arabalarını hatta evcil hayvanlarını bile değiştirebilmektedir.

Diğer yandan konukseverlik değiş tokuşlarında (Kanepe Sörfü olarak da adlandırılır) insanlar birbirlerini önceden belirlenmiş zaman çerçevesi içinde misafir etmektedir. Ev değiş tokuşu yapılan kişiler aynı evde birlikte kalırlar. Bu sistem bir nevi misafirlik gibidir. Bazı kişiler bu tür takası daha derin dostluklar kurduğu için tercih etmektedir. Bu sayede gidilen yeri oranın yerlisi tarafından tanıma fırsatı da yakalanmış olur. İnternet üzerinde faaliyet gösteren uluslararası misafirperverlik servislerinden bazıları: BeWelcome, CouchSurfing, Hospitality Club, Global Freeloaders'tır.

Günümüzde ev değişim sistemi \%99 internet üzerinden işlemektedir. Home Exchange, Ho- 


\begin{tabular}{|c|c|}
\hline $\begin{array}{l}\text { Çalışma ortamı paylaşımı } \\
\text { (Co-working) }\end{array}$ & $\begin{array}{l}\text { Citizen Space, Hub Culture, The Hub gibi sosyal ağlar, özellikle bağımsız çalışan kişilerin hem sosyalleşip } \\
\text { hem de çalışabilmesi için ortak çalışma alanları sağlarlar. }\end{array}$ \\
\hline Sosyal paralar & $\begin{array}{l}\text { Para yerine kullanılan farklı birimleri ve alternatif paraları kapsamaktadır. Para yerine zaman kullanan zaman } \\
\text { bankaları, Quid, Ven gibi alternatif para birimleri, LETSystems gibi kredi birimleri sosyal paralara örnektir. } \\
\text { Türkiye'de ise Zumbara para yerine zamanın kullanıldığı, yetenek ve tecrübelerin paylaşıldığı bir topluluktur. }\end{array}$ \\
\hline Taksi paylaşımı & $\begin{array}{l}\text { Adından da anlaşılacağı gibi bir taksiyi birden fazla kişinin anlaşarak kullanmasıdır. Taxi2, TaxiStop gibi örnekleri } \\
\text { vardır. }\end{array}$ \\
\hline Barter & Takas anlamına gelmektedir. Barterquest, OurGood gibi siteler hizmet, beceri ve malların takasına olanak sağlar. \\
\hline Bahçe paylaşımı & $\begin{array}{l}\text { Bahçesi olanla, bahçe işleriyle ilgili bilgisi olanı buluşturan veya ortak bahçe kullanımını sağlayan sitelerdir. } \\
\text { UrbanGardenShare, Landshare, SharedEarth gibi örnekleri vardır. }\end{array}$ \\
\hline Beceri paylaşımı & $\begin{array}{l}\text { Insanların yeteneklerini ve becerilerini birbirine öğretmesini sağlarlar. Brooklyn Skill Share, TeachStreet, } \\
\text { TradeSchool gibi web siteleri aracılığıyla insanlar becerilerini paylaşırlar. }\end{array}$ \\
\hline Kitle fonlama & $\begin{array}{l}\text { Çeşitli projeler veya kampanyalar için gerekli maddi desteği almak amacıyla internetin kullanılmasıdır. } \\
\text { IndieGoGo ve Kickstarter çok bilinmekle birlikte Türkiye'den Projemefon kitle fonlamaya örnektir. }\end{array}$ \\
\hline Sosyal yemek ağları & $\begin{array}{l}\text { Komşudan komşuya yemek hizmeti veren Gooble, Birlikte yemek yenilmesini sağlanan EatWithMe, "Hiçbir } \\
\text { zaman yalnız yeme" sloganıyla GrubWithUs yemek deneyiminin paylaşılması için kurulmuştur. }\end{array}$ \\
\hline Park noktaları & $\begin{array}{l}\text { Parkatmyhouse gibi sitelerde, insanlar evlerinin park yerini başka insanlara kiralayabilmekte veya kendileri başka } \\
\text { evlerden park yeri kiralayabilmektedir. }\end{array}$ \\
\hline Komşuluk desteği & $\begin{array}{l}\text { WeCommune, Streetbank gibi siteler belli bir çevrede oturan, birbirine yakın mesafedeki insanların tanışıp } \\
\text { birbirine destek olabilmesi için oluşturulmuştur. }\end{array}$ \\
\hline Kişiden kişiye seyahat & $\begin{array}{l}\text { Seyahate gidilen yerde bir kişinin evinde misafir olma veya oda kiralama gibi hizmetler sağlayan web siteleridir. } \\
\text { En popüleri Couchsurfing ve Airbnb'dir. Home exchange adı verilen ev değişimi versiyonları da vardır ve } \\
\text { Türkiye'den EvDeğişTokuşu'nu kullanmak mümkündür. }\end{array}$ \\
\hline
\end{tabular}

Kaynak: Tosuner 2012: 8-9, World Economic Forum 2013:5.

me Link ve Intervac ev değişimi konusunda en iyi olan üç sitedir (Akın, 2013). Bunun yanı sıra çok sayıda ulusal ve yerel site de vardır. Ev değiş tokuşuna olanak sağlayan, Türkiye'nin de dahil olduğu siteler şunlardır:

- www.homeexchange.com

- www.lovehomeswap.com

- www.homeforexchange.com

- http://homelink.org

- http://us.intervac-homeexchange.com

Ev değiş tokuşuna dahil olmak isteyenler, ilk olarak bu sitelere üye olmaktadır. Sitelerin genelde; üç aylık ve 12 aylık olmak üzere iki çeşit üyelik opsiyonu vardır. Ayrıca çoğu site deneme üyeliği de sağlar. Üye olduktan sonra herkesin kendi özel bir sayfası oluşur. Bu sayfada ev tanitılıp, fotoğraf yüklenebilir. Ev tanıtımında ne kadar çok bilgi verilirse ev karşı taraf için o kadar cazip hale gelmektedir. Ardından mahalle tanitılır. Son olarak da kişi kendini tanıtıp gitmek iste- diği yerlerin listesini ve tarihlerini belirtir. Böylece kişisel sayfa siteye girmiş olur. Geriye kalan tek şey, ev değişimi konusunda tarafların karşılıklı iletişimi ve anlaşmasıdır.

Ev değişimi son zamanlarda hızla büyüyen bir niş fenomen olmasına rağmen bu konuda alanyazında çok az sayıda çalışma olduğu görülmüştür. Ev değişiminin turizm pazarında alternatif bir ürün olarak nitelendirildiği ilk çalışma Groote ve Nicasi'nin (1994) çalışmasıdır. Yazarlar bu konuda Belçika pazarında bir SWOT analizi gerçekleştirmişlerdir. Kapsamlı bir diğer çalışma ise 2006 yılında yapılan Arente ve Kiiski'nin çalışmasıdır. Çalışmada, sosyolojik teorileri arka plana alarak postmodern tüketim incelenmiş ve bu durum ev değiştiren kişilerle derinlemesine görüşmeler yapılarak analiz edilmiştir. Yine bir diğer çalışmada Grit, 2008 yılında ev değişim kurumlarının gelişim analizi incelemiştir. Forno ve Garibaldi (2013) tarafından yapılan çalışma ise nitel yönteme dayanmaktadır. Yazarlar çalışmalarında, ev 
değiştiren kişilerin profillerini, motivasyonlarını ve seyahat alışkanlıklarını analiz etmişlerdir.

\section{Günlük Ev Kiralama}

Son dönemlerde konut kiralama modelinin değişik bir ayağı olan 'Günlük Ev Kiralama' oldukça popüler hale gelmiş olup bu tür işlemlerin sayısı her geçen gün artmaktadır. Özellikle büyükşehirlerin merkezi bölgelerinde yaygın olarak yapılan günlük kiralamalar, normal kiralamalara göre hem daha fazla gelir getirmesi hem de daha az prosedür içermesi yönüyle ev sahipleri açısindan avantajlı hale gelmektedir. Bu durum ev sahipleri için avantajlı olduğu kadar kısa süreli konaklama ihtiyacı olan kiracılar için de oldukça avantajlıdır.

Kısa süreli konaklama ihtiyacı olan kiracılar konaklama yapacakları süreyi, bir otelde düşük konfor ve yüksek maliyetle yapmaktansa günlük kiralık bir ev tutup burada ev ortaminda ve düşük maliyetle gerçekleştirebilmektedirler. Kayıt dışılık oranının oldukça yüksek olduğu bu pazarda vergi kaybı da büyük rakamlara ulaşmaktadir.

Günlük ev kiralama faaliyetleri, bu hizmeti sunan web siteleri yoluyla gerçekleştirilmektedir. Türkiye'nin de dahil olduğu sitelerden bazıları ise şunlardır:

- www.airbnb.com.tr/

- www.hemenkiralik.com/

- www.facebook.com/9flats

- www.wimdu.com.tr/

- www.myfriendshotel.com

- www.tripping.com

- www.homelidays.com

- www.roomorama.com

- www.istopover.com

- www.housetrip.com

Ev kiralama sitelerinin en önde geleni Airbnb'dir. Her ne kadar sitede listelenen evlerin çoğunluğu ABD'de bulunsa da Airbnb Endonezya'dan Brezilya'ya kadar 190'dan fazla ülkede ve binlerce şehirde ev ve oda kiralama olanağı sunmaktadır. Bu sistemde, ilk olarak gi- dilecek şehre ve tarihe karar vermek, daha sonra sitede arama yaparak çıan evlerden birini seçmek gerekmektedir. Ardından ev sahibine mesaj atarak uygunluğu sorulmakta, eğer her şey uygunsa Paypal kullanarak ödeme gerçekleştirilmektedir. Airbnb sistemi bu parayı tutmakta ve kişi eve giriş yaptıktan bir gün sonra ev sahibine para transferini gerçekleştirmektedir. Böylece güvenli bir alış veriş de sağlanmış olmaktadır. Ayrıca, Airbnb ile bir nevi acente, emlakçı, komisyoncu vb. aracılar ortadan kaldırılarak daha az ücretle hızlı biçimde konaklayacak yer bulma şansı da yakalanmış olmaktadır.

Yürek (2014), çalışmasında günlük kiralamanın avantaj ve dezavantajlarını şu şekilde sıralamıştır:

\section{Günlük ev kiralamanin avantajları:}

- Yatırımcilar yönüyle 1+0 ve 1+1 ev tipinin sat1şını kolaylaştırmaktadır.

- Günlük kazanç imkânı doğmakta ve kazanılan para, mal sahibinin aylık bazda elde edeceği kira bedelinden daha cazip hale gelmektedir.

- Konut tapusu olmasına rağmen meskenin ticari amaçla kullanımı mal sahibinin emlak vergisi haricinde vergi ödememesine neden olmaktadir.

- Konutun kiralanması yüzde 90 internet üzerinden yapıldığından komisyon bedeli, ek ilan bedeli vs. ödenmemektedir.

- Büyük şehirlere ister kısa ister uzun süreliğine iş seyahati için gidenlerin otel masraflarına k1yasla daha ekonomik bir faturayla karşılaşmaları olanağı doğmaktadır.

\section{Günlük ev kiralamanin dezavantajlarl:}

- Günlük kira ödemelerinin banka kanalı yerine elden yapılması sonucunda vergisel açıdan denetim zor hale gelmektedir.

- Söz konusu evlerin kiralanması faaliyeti ile uğraşanlar, elde ettikleri kazanç nedeniyle yıllık gelir vergisi beyannamesi vermemektedir.

- Daha yüksek kira ödemesi yapan ve yasadışı faaliyetlerde bulunanlara söz konusu faaliyetleri gerçekleştirebilmeleri için evler kısa süreli kiralanmaktadır. 
- Yüksek getiri sebebiyle ev sahipleri yasa dışı faaliyetlere göz yummaktadır.

- Günlük kiralamaların internet üzerinden ilan verilmek suretiyle yapılması nedeniyle kişi bazında takibi zor hale gelmektedir.

- Günübirlik sözleşmeler yapılması gerekirken bunun yerine kiracilardan yalnızca kimlik bilgilerinin alınması ile kiralama yapılmaktadır. Hatta bazı durumlarda saatlik yapilan kiralamalarda kimlik bilgileri dahi alınmadan kiralama yapılmaktadir.

- Kiralanan evlerin hangi amaçlara yönelik olarak kullanıldığının denetimi yapılmamaktadır.

Günlük kiralık ev trendinin artan etkisi araştırmacıların da bu konuya ilgisini arttırmış ve son dönemde özellikle Airbnb üzerine birçok çalışma yapılmıştır (Guttentag 2015; Finley 2013; Zervas vd. 2014; Edelman ve Luca 2014; Kurtz 2014). Lieber, 2011 yılında Airbnb'yi test etmiş ve temizlik, gürültü gibi sorunları olduğunu çalışmasında bildirmiştir. 2013 yılında yapılan çalışmalarda ise Grant, Airbnb'nin geleneksel konaklama işletmelerine karşı sınırlı sayıda bir rekabet yaratacağını; Mayock da yine benzer bir argümanda ("Kişiden kişiye rezervasyon siteleri bir tehdit değil" adlı makalesinde) Airbnb'nin kiralık evlerinin sayısının Amerika'nın Güney Atlantik bölgesindeki otel odalarının dörtte birine denk geldiğini belirtmiştir. Tabi bu çalışmalar 2013 yılındaki verilerle oluşturulmuştur. Günlük ev kiralama siteleri ilanlarını her gün arttırmakta ve bu veriler de sürekli değişmektedir.

\section{ARAŞTIRMANIN AMACI VE ÖNEMI}

$\mathrm{Bu}$ araştırmanın amacı, resmi olmayan konaklama sektöründeki değiş tokuş ve günlük kiralık ev trendinin, geleneksel konaklama sektörü üzerinde olası etkisinin olup olmadığını açıklamaya çalışmaktır. Değiş-tokuş ve kiralama uygulamalarıyla ilgili daha önce yapılan çalışmalarda (Lieber 2011; Forno ve Garibaldi 2013) kullanıcı profilinin belirlenmesine odaklanıldığ 1 ve bu uygulamaları sunan web sitelerine ilişkin herhangi bir çalışma yapılmadığı görülmüş̧ür. Bu bağlamda bu araştırma ile ilk olarak değiş tokuş ve kirala- ma faaliyetleri sunan web sitelerine ilişkin özellikler tanımlanacak, ardından siteler biçim ve içerik açısından çözümlenerek geleneksel konaklama işletmeleri üzerindeki etkileri belirlenmeye çalışılacaktır. Araştırmanın bu amacından hareketle, ilgili alanyazın incelenmiş ve araştırmayla aşağıdaki sorulara cevap aranmıştır.

Ev değiş tokuşu ve günlük ev kiralama (alternatif konaklama) olanağı sunan web siteleri/sitelerinin;

1. Amaçları nelerdir?

2. Kullanıcılarına ne tür hizmetler sunmaktadır?

3. Ne kadar kişi tarafından kullanılmaktadır? Kullanıcı profili kimlerden oluşmaktadır?

4. Kullanıcilar tarafindan neden geleneksel konaklama işletmelerine tercih edilmektedir?

5. Kullanıcılarına nasıl güven vermektedir? (Web sitesi ve kullanıcı arasında güven doğuran mekanizmalar nelerdir?)

6. Kullanıcılarının algıladıkları riskler nelerdir?

7. Geleneksel konaklama işletmeleri üzerindeki etkileri nelerdir?

Böylece sitelerin sundukları hizmetlerin genel bir değerlendirmesi ve karşılaştırması da yapılmış olacaktır.

Araştırma, hem sayıları her geçen gün artan ama yasal bir altyapısı ve denetiminin olmadığ 1 alternatif konaklama endüstrisini hem de bu olanağı sunan web sitelerinin geleneksel konaklama endüstrisine olan etkisini incelemesi ve üzerinde çok fazla çalışma yapılmayan paylaşım ekonomisi kavramı ile ilgili alanyazına katkı sağlaması açısından önemlidir.

\section{ARAŞTIRMANIN YÖNTEMI}

"Paylaşım ekonomisi" kavramının ele alındığı bu çalışmada veriler, araştırılması hedeflenen olgu veya olgular hakkında bilgi içeren yazılı materyallerin analizini kapsaması ve araştırmanın amacina uygunluğu nedeniyle nitel araştırma yöntemlerinden doküman incelemesi yoluyla toplanmiştır.

Doküman incelemesi, önceden var olan ya da oluşan materyallerin kullanılmasıdır (Scott ve 
Tablo 4. Araştırma Sürecinde İncelenen Alternatif Konaklama Siteleri

\begin{tabular}{|c|c|}
\hline \multicolumn{2}{|l|}{ Ev değiş tokuşu olanağı sunan; } \\
\hline $\begin{array}{l}\text { - HomeLink } \\
\text { (http://homelink.org/tr/) }\end{array}$ & $\begin{array}{l}1953 \text { yılından beri hizmet veren, Dünyanın ilk ev değişim sitesidir. Pek çok ev değişim } \\
\text { organizasyonundan farklı olarak, HomeLink dünyada } 27 \text { farklı dilde temsilciye sahiptir. } \\
\text { Günlük ev kiralama olanağı sunan; }\end{array}$ \\
\hline $\begin{array}{l}\text { - Hemen Kiralık } \\
\text { (http://www.hemenkiralik.com/) }\end{array}$ & $\begin{array}{l}\text { HemenKiralik.com, Türkiye'de profesyonel olarak uygulanan ilk online kiralama portalıdır. } \\
\text { İlk olarak } 2011 \text { yıının Aralık ayında Remi Onur, Alper Kaya ve Mehmet Ülkü tarafindan üç k } \\
\text { işilik kadro ile kurulmuştur. Bir yıl sonra bu sayı 27’ye ulaşmış, şu anda ise şirket bünyesinde } \\
32 \text { kişi çalışmaktadır. Hemen Kiralık, Remar Bilgi Teknolojileri Turizm ve Pazarlama A.Ş.'nin } \\
\text { tescilli bir markasıdır. }\end{array}$ \\
\hline $\begin{array}{l}\text { - Wimdu } \\
\text { (http://www.wimdu.com.tr/) }\end{array}$ & $\begin{array}{l}\text { Wimdu Mart } 2011 \text { 'de, Arne Bleckwenn ve Hinrich Dreiling tarafindan kurulmuştur. Küçük bir } \\
\text { ekip olarak başlasa da bugün dünya çapında kendini işine adamış } 250 \text { çalışanın oluşturduğu } \\
\text { bir gruba dönüşmüştür. Halen hızla büyüyen Wimdu, şu anda her zevk ve bütçe için özel } \\
\text { konaklama olanakları sunan önde gelen bir online platformdur. Dünya çapında, misafir ve ev } \\
\text { sahiplerinin iletişimini sağlayarak, otellere bir alternatif arayanlara eğlenceli ve otantik } \\
\text { seyahat tecrübesi sunmaktadır. }\end{array}$ \\
\hline
\end{tabular}

Kaynak: Home Exchange, Love Home Swap, Home Link, Airbnb, Hemen Kiralık ve Wimdu sitelerinin web sayfaları incelenerek oluşturulmuştur, 15 Aralik 2014.

Morrison 2005). Duverger' in (1973) “belgesel gözlem" diye adlandırdığı bu yöntemi, Rummel (1968) ve birçok araştırmacı "doküman metodu" olarak adlandırmışlardır. Best (1959) ise bu yöntemi "mevcut kayıt ya da belgelerin, veri kaynağ 1 olarak, sistemli incelenmesi" olarak tanımlamıştır. Bu tür araştırmalarda, araştırmacı ihtiyacı olan veriyi gözlem veya görüşme yapmadan elde edebilir (Yıldırım ve Şimşek 2005). Diğer yandan materyalin hazır olması, veri toplama sürecini araştırmacının öznelliğinden kurtarır (Mayring 2000: 36).

Doküman analizi yöntemi sosyal bilimler alanında yaygın olarak kullanılan yöntemlerden biridir ve dokümanlar, nitel araştırma kapsamında değerlendirilir. Bu yönüyle araştırma nitel bir çalışmadır ve tarama modelinde desenlenmiştir.

\section{Evren ve Örneklem}

Araştırmanın evrenini, ev değiş̧-tokuşu ve günlük ev kiralama olanağı sunan web siteleri oluşturmaktadır. Araştırma nitel bir çalışmadır ve burada amaç genellenebilir bilgilere ulaşmak değil sadece incelenen durumu keşfetmektir. Genelleme kaygısı olmadığından örneklem konusunda standartlaştırılmış öneriler de yoktur. Bu nedenle araştırmadaki örneklem sayısı altı olarak belirlenmiştir.

Alternatif konaklama olanağ te, amaçlı örnekleme yöntemlerinden; benzeşik örnekleme, ölçüt örnekleme ve kolay ulaşılabilir durum örneklemesinin beraber kullanılması sonucu araştırmanın örneklemi olarak belirlenmiştir. Araştırmanın veri kaynağı, diğer bir deyişle araştırmada doküman olarak kullanılan web siteleri Tablo 4'te sunulmuştur: 
Web sitelerinin seçiminde; alanında en iyi ve en çok kullanılan siteler olmaları, kolay ulaşılabilmeleri, çalışmanın amaçladığı boyutları bünyelerinde barındırmaları ve Türkiye'nin de bu sitelere dahil olması etkili olmuştur.

\section{Veri Analizi}

Araştırmada dokümanlardan elde edilen veriler; nitel veri analizinde sıklıkla kullanılması, herhangi bir yazılı metni ya da belgeyi inceleme fırsatı vermesi, verileri sayısal veya istatistiksel olarak sunma olanağı sağlaması gibi özelliklerinden dolayı doküman inceleme yaklaşımlarından biri olan içerik analizi yardımıyla çözümlenmiştir.

İçerik analizi, yöntem olarak araştırmacının araştırma verilerini, belirlediği birtakım ölçütlere göre incelemesi temeline dayanmaktadır. Bilgin (2006:1), içerik analizini, çok çeşitli söylemlere uygulanan birtakım yöntemsel araç ve tekniklerin bütünü olarak tanımlarken, içerik analizi tekniklerinin ise bir söylemi anlama ve yorumlamada, öznel etkenlerden kurtulmayı sağlama amacı taşıdığını belirtmektedir. Cohen vd. de (2007) içerik analizini, eldeki yazılı bilgilerin temel içeriklerinin ve içerdikleri mesajların özetlenmesi ve belirtilmesi işlemi olarak tanımlamaktadır. $\mathrm{Bu}$ açıdan araştırma, keşifsel nitelikli bir çalışmadır ve çalışmada içerik analizi türlerinden "kategori ve değerlendirme analizi" kullanılmıştır.

Her bir araştırma sorusu konunun bir boyutunu ele almakta ve içerik analizi çalışmada yedi kategori altında yapılmaktadır. Bu kategoriler;

1. Site amaçları,

2. Sunulan hizmetler,

3. Kullanıcı profili,

4. Tercih edilme nedenleri,

5. Güven oluşturma yaklaşımları,

6. Riskler ve

7. Geleneksel konaklama işletmeleri üzerindeki etkiler'dir.

İçerik analizinde, dokümanlardan elde edilen nitel araştırma verilerinin işlenmesi, verilerin kodlanması, temaların bulunması, kodların ve temaların düzenlenmesi, bulguların tanımlan- ması ve yorumlanması şeklinde dört aşama bulunmaktadır (Yıldırım ve Şimşek 2005). Bu çalışmada da elde edilen veriler içerik analizi işlem basamaklarına (Yıldırım ve Şimşek 2005: 193; Silverman 2005: 89) göre incelenmiştir: Birinci aşamada ne tür dokümanlara ihtiyaç duyulduğu belirlenmiş, ikinci aşamada dokümanlar internet ortamındaki web sitelerinden elde edilmiştir. Üçüncü aşamada, bu dokümanlar belirli bir sisteme göre ve birbirleriyle karşılaştırılarak çözümlenmiştir. Web dokümanlarının analizi alanında kilit noktalardan biri, web dokümanının tamamındaki büyük bilgi yığını üzerinde can alıcı bilgiyi kaybetmeden kodlama yapmaktır (Sinka ve Corne 2004). Bu anlamda, değiş tokuş ve kiralama uygulamaları sunan web sitelerinin; amaçlarının neler olduğuna, kullanıcılarına sundukları hizmetlere, ne kadar kişi tarafından kullanıldıklarına, kullanıcı profillerine, tercih edilme nedenlerine, nasıl güven verdiklerine ve risklerine ilişkin veriler araştırma amaçları doğrultusunda kodlanmıştır. Alanyazında farklı işletme türlerinin web sayfalarını konu alan benzer çalışmalara rastlamak mümkündür. Bu aşamada web sitesi içerik analizi konusunda yapılan çalışmalarda kullanılan kriterler incelenmiş (Kurulgan ve Bayram 2006; Marangoz vd. 2012; Dalgın ve Karadağ 2013), bu çalışmalardan ve örneklemi oluşturan siteler ile ilgili değerlendirmelerden yola çıarak araştırmanın kriterleri (değerlendirme ölçütleri) belirlenmiştir. Dördüncü aşamada, dokümanlar kapsamlı içerik analizine tabi tutulmuş ve araştırma soruları doğrultusunda oluşturulan yedi kategori altında içerik analizi gerçekleştirmiştir. Ortaya çıan veriler ise tablolaştırılmış ve dokümanlardan yapılan doğrudan alıntılarla desteklenmiştir.

\section{Geçerlilik ve Güvenilirlik}

İçerik analizinde geçerliliğin sağlanabilmesi, araştırmanın amaçları ve araçları arasındaki uyuma bağlıdır (Gökçe 2006: 83; Bilgin 2006: 17). İçerik analizinde kategorilerden başka geçerliliği ölçme aracı yoktur. Bu nedenle içerik analizinde kategorilerin herkesçe paylaşılabilir nitelikte olması ve aşamaların iyi tanımlanmış olması gerekmektedir. Güvenilirlik ise özellikle kategori 
sistemi ve buna bağlı olarak kodlama işlemiyle sağlanmaktadır. Bu bağlamda gerçekleştirilen bu araştırmanın geçerlilik ve güvenilirliğinin sağlanması için, kuramsal yapı temel alınarak kategorilerin belirlenmesi sağlanmıştır. Elde edilen veriler sistematik olarak analiz edilmiş, kategoriler ve kodlamalar tablolaştırılarak değerlendirilmiştir. Araştırmada izlenilen süreç, açıkça belirtilmiştir. Bu hususların araştırmanın geçerlilik ve güvenilirliğine ilişkin kaygıları azaltıcı yönde olduğu belirtilebilir.

\section{ARAŞTIRMANIN BULGULARI VE YORUMLANMASI}

Araştırma bulguları değiş-tokuş ve kiralama olarak iki bölümde analiz edilmiştir. İlk olarak ev değiş-tokuşu olanağı sunan üç sitenin, ardından günlük kiralama faaliyeti sunan üç sitenin araştırma soruları doğrultusunda analizi yapılmıştır. Analizlerden elde edilen bulgular aşağıda sırasıyla yer almakta olup, bazı bulgular karşılaştırmalı olarak tablo halinde sunulmaktadır.

\section{Değiş Tokuş Sitelerine illişkin Bulgular}

\section{Değiş Tokuş Sitelerinin Amaçları}

Tablo 1'de yer alan ev değiş-tokuşu olanağı sunan web sitelerine ilişkin veriler incelendiğinde sitelerin kişiden kişiye seyahati geliştirmek adına birtakım amaç ve hedefler belirlediği ortaya çıkmiştır. Genel olarak "konaklamaya para ödemeden yerlisi gibi yaşayın" sloganını kullanan bu değiş tokuş sitelerinin amaçları ekonomik ve sosyokültürel boyut altında aşağıdaki şekilde özetlenebilir;

\section{Ekonomik amaçlar:}

- Tasarruf olanağı sağlamak,

- Daha fazla üyeye ulaşmak,

- Tüm dünyaya seyahat etme olanağı sağlamak,

- Yerel ekonominin kalkındırılmasını sağlamak.

\section{Sosyo-kültürel amaçlar:}

- Kentte yaşayan insanların sosyal etkileşim ihtiyacını giderebilmek,

- İnsanların birbirleriyle paylaşımını arttırarak daha barışçıl, daha anlayışlı ve saygılı bir birliktelik oluşturulmasına katkı sağlamak,
- Aynı fikirleri paylaşan insanları bir araya getirmek,

- İnsanların biribirinin evini kullanırken, sorumluluk sahibi bir birey gibi davranmalarını sağlamak,

- Yeni yer ve kültürlerin keşfedilmesini sağlamak,

- Dünyanın değişik yerlerinde arkadaş edinmeyi sağlamak,

- Yerel halkı daha iyi tanıtma firsatı bulmak,

- Gidilen destinasyonda, oranın yerlisi gibi tatil yapma olanağı sağlamaktır.

\section{Değiş Tokuş Sitelerinin Sunduğu Hizmetler}

Tablo 5'te alışılagelmiş tatil programlarının aksine, karşılıklı olarak evlerin değiştirilmesini sağlayan sisteme üye olarak, istenilen ülkede konaklama ücreti ödemeden tatil yapma olanağı sunan web sitelerinin sunduğu hizmetler karşılaştırılmıştır (Bkz. Tablo 5).

$\mathrm{Bu}$ üç site incelendiğinde her birinin çeşitli dillerde hizmet verdiği tespit edilmiştir. Bu sayede birçok ülke vatandaşı bu sitelerden arzu ettiği şekilde faydalanabilmektedir. Bu durum erişilebilirliğin kullanıcılar açısından ne kadar kolay olduğunun da bir göstergesidir.

Sitelerin turistik konaklamaya yönelik sunduğu hizmetler ise şu şekilde belirlenmiştir:

Ev Tercihi: Ev değişimi yapmak isteyen üyelerin özelliklerine göre kalınacak evler ayarlanabilmektedir. Örneğin; çocuklu aileler için evler, evcil hayvanların kabul edildiği evler gibi birçok alternatif mevcuttur. Üyeler değişim tercihlerini de siteler vasıtasıyla belirtebilmektedir (Örn.: Sigara içilmez).

Düzenli ve Hijyenik Konaklama: Sitelerde evlerin temiz bir şekilde teslim edilmesi kuralı belirtilmiştir. Ayrıca evler, gelecek olan kişilerin ihtiyaçlarına göre yeniden düzenlenmiştir (Poşet içinde havlular, özel dolaplar, hijyenik kuralara uygun temiz banyo, tuvalet ve mutfak). Yani bu evlerde hem yerlisi gibi yaşanmakta hem de oteldeki gibi hijyen ve temizlik bulunabilmektedir.

Yöresel Yemekler: Ev değişimi gerçekleştiren ev sahipleri, evden çıkmadan önce buzdolabına ye- 
Tablo 5. Değiş Tokuş Sitelerinin Sunduğu Hizmetler

\begin{tabular}{|c|c|c|c|}
\hline Hizmetler & Home Exchange & Love Home Swap & Home Link \\
\hline Site tanımı/tarihi & $\bullet$ & & $\bullet$ \\
\hline Sistemin işleyişi bilgisi & $\bullet$ & $\bullet$ & $\bullet$ \\
\hline Kullanım şartları & - & & \\
\hline Politikalar & $\bullet$ & & $\bullet$ \\
\hline Yardım merkezi & $\bullet$ & $\bullet$ & • \\
\hline $\begin{array}{l}\text { Temsilciler ekibi } \\
\text { (Türkiye Temsilcisi) }\end{array}$ & Mirey Mesayyah (İstanbul) & & $\begin{array}{r}\text { Samim Er } \\
\text { (İzmir) }\end{array}$ \\
\hline Üyelik & $\begin{array}{r}15.95 \mathrm{TL} \\
\text { (aylık) }\end{array}$ & $\begin{array}{r}\text { Gümüş üyelik } 20 \$ \\
\text { Altn üyelik } 23 \$ \\
\text { Platin üyelik } 34 \$ \\
\text { (aylık) }\end{array}$ & $\begin{array}{r}200 \mathrm{TL} \\
\text { (yıllık) }\end{array}$ \\
\hline Ödeme seçenekleri & Paypal ve kredi kart & & $\bullet$ \\
\hline Koşullar ve Gizlilik & $\bullet$ & & • \\
\hline Kiralama & & $\bullet$ & $\bullet$ \\
\hline Fotoğraflar & $\bullet$ & - & • \\
\hline Kullanıcı Yorumları & $\bullet$ & & \\
\hline Basında yer alan haberler & $\bullet$ & $\bullet$ & - \\
\hline Mobil desteği & $\bullet$ & $\bullet$ & • \\
\hline Güvenlik & $\bullet$ & $\bullet$ & - \\
\hline Sıkça sorulan sorular & $\bullet$ & $\bullet$ & $\bullet$ \\
\hline Dil seçenekleri & 16 dil seçeneği & $\begin{array}{r}2 \text { dil seçeneği } \\
\text { (Ingilizce ve Fransızca) }\end{array}$ & 12 dil seçeneği \\
\hline Sosyal medya bağlantısı & $\bullet$ & $\bullet$ & - \\
\hline Güncellik & $\bullet$ & $\bullet$ & - \\
\hline Kullanışlılık & • & $\bullet$ & $\bullet$ \\
\hline Deneme süresi & Ücretsiz 14 gün & Ücretsiz 14 gün & 75 TL üç aylık \\
\hline Illetişim & $\bullet$ & $\bullet$ & • \\
\hline
\end{tabular}

Kaynak: https://www.homeexchange.com/tr/; http://www.lovehomeswap.com/; http://homelink.org/tr/, 20.12.2014.

rel yemeklerden koyarak evini kullanacak kişiye bir hoş geldin hediyesi vermektedir.

Alış-Veriş Olanağı: Misafirler, ev sahibinin daha önce evini tanıtırken bahsettiği yerel çevredeki noktalardan yöreye özgü ürünler ve hediyelik eşya alış-verişi yapabilmektedirler.

\section{Değiş Tokuş Siteleri Kullanıcıları}

Değiş-tokuş sitelerinin Türkiye'den ve dünyanın değişik yerlerinden üyeleri vardır. Ancak incelenen sitelerde değiş tokuş sistemine yönelik hiçbir kesin istatistiki veri bulunmadığı görülmüştür. (Bkz. Tablo 6). Türkiye'den Home Exchange'de

Tablo 6. Değiş Tokuş Sitelerine Yönelik İstatistiki Veriler (yaklaşık)

\begin{tabular}{lrrr}
\hline Site & Üye sayısı (+) & Hizmet verdiği ülke sayısı (+) & Yapılan değiş-tokuş sayısı (+) \\
\hline Home Exchange & 55.000 & 150 & 1.000 .000 \\
\hline Love Home Swap & 60.000 & 160 & 700.000 \\
\hline Home Link & 22.000 & 90 & \\
\hline
\end{tabular}

Kaynak: https://www.homeexchange.com/tr/; http://www.lovehomeswap.com/; http://homelink.org/tr/, 20.12.2014. 
Tablo 7. Değiş Tokuş Sitelerinin Tercih Nedenleri

- Maliyet tasarrufu sağlama,

- Ev rahatlığında tatil yapma,

- Alternatif konaklama (tekne, değirmen, şato, kır evi...) olanağı bulma,

- Kültürel deneyim firsat edinme,

- Başka ailelerin yaşamını yakından görebilme,

- Paylaşım ekonomisine katkı sağlama düşüncesi,

- Turizm pazarındaki yeni eğilimlere uyum sağlama,

- Ev değiş tokuşu süresince evin sahipsiz kalmaması,

- Daha hür ve esnek bir tatil geçirme şansı elde etme,

- Daha çok mahremiyet,

- Aynı düşünceyi paylaşan kişilerle dostluk ve iyi ilişkiler kurma isteğidir.

Kaynak: https://www.homeexchange.com/tr/, http://www.lovehomeswap.com/ ve http://homelink.org/tr/ web adresleri incelenerek oluşturulmuştur.

114, Love Home Swap'ta 240 ve Homelink'te 61 kayıtlı ev bulunmaktadır.

Sitelerin kullanıcı profilini ise öğretmenler/eğitimciler, emekliler, üst düzey yöneticiler, mühendisler, modacılar, bankacılar, doktorlar, avukatlar gibi meslek sahibi ve eğitimli kesimin oluşturduğu görülmüştür. Bu profilin oluşmasında sitelerin uyguladığı politikalar da (Örneğin; üniversite profesörlerinin ücretli izinleri süresince ev değişimi-HomeLink) etkili olmuştur. Ayrıca, bu kişilerin çoğu maceraperest ve yeni yerler görüp yeni şeyler öğrenme hevesiyle dolu olan kişilerdir.

\section{Değiş Tokuş Sitelerinin Tercih Nedenleri}

Genel olarak "ekonomik getirisinin yanında yerlisi gibi tatil yapabilmeyi bekliyoruz" ifadelerini kul- lanan kullanıcıların sitelere üye olma nedenleri Tablo 7'de verilmektedir.

\section{Değiş Tokuş Sitelerinin Güven Oluşturma Yaklaşımları}

Web sitelerinin pazarlanmasında güven kavramı işletmeler için en önemli konudur. Çünkü güven, tüketicilerle uzun süreli ilişkiler kurulması ve sürdürülmesinin temelini oluşturmaktadır. Herkese açık olan ağ ortamlarında, kişisel bilgilerin kötü amaçlı kullanımına engel olmak için her türlü işlemin gizlilik içinde gerçekleşmesi gerekir.

Home Exchange, Love Home Swap ve HomeLink siteleri incelendiğinde güven oluşturma yaklaşımları ile ilgili şu sonuçlara varılmaktadır (Bkz. Tablo 8):

Tablo 8. Değiş Tokuş Sitelerinin Güven Oluşturmak İçin Müşterilerine Vermiş Olduğu Hizmetler

\begin{tabular}{|c|c|c|c|}
\hline & Home Exchange & Love Home Swap & Home Link \\
\hline Farklı dillerde hizmet verir. & • & • & • \\
\hline Kullanıılarının kişisel bilgilerini şifreleyerek güvenli hizmet sunar. & • & • & $\bullet$ \\
\hline Daha önce konaklama yapan kullanıcıların tecrübelerini yorum olarak sitede yayınlar & lar. & & \\
\hline Güvenlik platformu oluşturur. & - & • & • \\
\hline Detaylı üye profili oluşturulmasını sağlar. & • & • & $\bullet$ \\
\hline Temsilciler ekibi kurar. & • & & • \\
\hline Değiş-Tokuş sözleşmesi hazırlar. & • & & • \\
\hline Ödeme için seçenekler sunar. & • & & • \\
\hline Acil durumlar için iletişim bilgileri bulunur. & - & & \\
\hline
\end{tabular}

Kaynak: https://www.homeexchange.com/tr/; http://www.lovehomeswap.com/; http://homelink.org/tr/, 21.12.2014. 


\section{Değiş Tokuş Uygulamalarının Riskleri}

Her değiş tokuş özeldir, karşılıklı güven ve iyi niyete dayanır. Ev değiş tokuşu olanağ1 veren siteler bu uygulamaların her ne kadar güvenli olması için çalışsa da algılanan bir takım riskler vardır ve bu riskler her iki taraf için de geçerlidir.

Araştırma kapsamında incelenen sitelerdeki kullanıcı yorumlarından kişilerin; acil ve beklenmedik durumlar (su basması, yangın vb.), gürültü, temizlik, açıklamalar, yorumlar, konuk süreci, dürüstlük, kişisel güvenlik, sorunların nasıl çözüleceği ve kültürel deneyim konularında bir takım riskler algıladıkları sonucuna ulaşılmıştır.

\section{Değiş Tokuş Uygulamalarının Geleneksel Konaklama İşletmeleri Üzerindeki Etkileri}

Değiş tokuş uygulamaları sunan siteler sayesinde artık insanlar evlerini değiş tokuş ederek dünyanın başka bir kentinde daha ekonomik bir tatil geçirme firsatı yakalamaktadır. 1953'te Homelink ile ortaya çıkan fakat sadece belli bir kesimin farkında olduğu, ev değiş tokuş ederek tatil yapma uygulaması ekonomik krizin etkisiyle günümüzde ise bir trend halini almıştır. Home Exchange, Love Home Swap ve Homelink gibi internet siteleri, krizin tüm dünyayı etkilediği 2009 yılı içinde yüzde 30 artarak ayrı bir pazar oluşturmuştur.

Otellere para vermek istemeyen tatilcilerin büyük ilgi gösterdiği değiş tokuş sistemi, kullanıc1larından yıllık 190 TL'den 940 TL'ye kadar farklı üyelik ücretleri almakta ve bunun karşılı̆̆ında sistemdeki diğer üyelerle sınırsız sayıda ev değişimi gerçekleştirme olanağı sunmaktadır. Bir haftadan birkaç yıla kadar ev değiş tokuşu yapma firsatının olduğu bu sistem Türkiye'de de yükselen bir değer olarak görülmektedir. Başta İstanbul ve Muğla olmak üzere güney bölgelerinde bulunan tatil beldelerindeki birçok ev bu sisteme üye olmuştur. Özellikle tatil bölgelerinde bulunan evlerin denize yakın olması ön plana çıkartılırken, İstanbul'da yeni geçici sahiplerini bekleyen evlerin boğaz manzarası görüp görmediği ya da şehir merkezine yakınlığı önemli ölçütler arasında yer almaktadır. Evlerin merkezi konumda yer alması, rahatlığ1 vb. özellikleri bir de üstüne para ödemeden oranın yerlisi gibi bir tatil alternatifi sunması site kullanıcılarının bu evleri geleneksel konaklama işletmelerine tercih etmelerine yol açmaktadır.

\section{Günlük Kiralık Sitelerine İlişkin Bulgular}

\section{Günlük Kiralık Sitelerinin Amaçları}

Değişen şartlar ve teknolojiyle, son dönemde konut kiralama modelinin değişik bir ayağı olan “Günlük Ev Kiralama” oldukça popüler hale gelmiş olup bu tür işletmelerin sayısı her geçen gün artmaktadır. Bu eğilimden yararlanmak isteyen kişileri bir araya getiren üç web sitesinin analizi sonucunda, sitelerin ev paylaşımı konusunda benzer amaçları olduğu görülmüştür.

"Ev konforunda konakla" (Hemen Kiralık), "Evinize hoş geldiniz" (Airbnb) gibi sloganları kullanan bu günlük ev kiralama sitelerinin kullanıcılarına "beş yıldızlı otellerden daha hesaplı ve konforlu konaklama” olanağı sunmak için belirledikleri genel amaçlar şu şekilde özetlenebilir;

- Daha fazla kullanıcıya ulaşmak,

- Ekonomik katkı sağlamak,

- Güvenli alış veriş olanağı sunmak,

- Topluluk oluşturmak,

- Dünya çapında konaklama firsatı sunmak,

- Insanların birbirleriyle paylaşımını arttırmak,

- Aynı fikirleri paylaşan insanları bir araya getirmek.

\section{Günlük Kiralama Sitelerinin Sunduğu Hizmetler}

Tablo 9'da günlük kiralık ev olanağı sunan Airbnb, Hemen Kiralık, Wimdu sitelerinin, sistemlerini daha çekici hale getirerek daha fazla kullanıcıya ulaşmak adına üyelerine sundukları hizmetler karşılaştırılmış ve tablo halinde sunulmuştur.

Tablo 9'da da görüldüğü gibi kullanıcılarına en fazla bilgi hizmetini sunan site Airbnb'dir. Bunun nedenleri arasında sitenin alanında en eski ve en popüler site olması gösterilebilir. Altı yılı aşkın tecrübeleri, sitenin sürekli kendini yenilemesini sağlamıştır. Sitede en son yapılan yenilik olarak sisteme kayıtlı evler; modern villalar, çiftlikler, yel değirmenleri, ağaç evler, lüks yatlar, şatolar, karavanlar, peri masalı evleri, tekneler, 
Değiş Tokuş ve Kiralama Uygulamalarının Konaklama İşletmeleri Üzerindeki Olası Etkileri

Tablo 9. Günlük Ev Kiralama Sitelerinin Sunduğu Hizmetler

\begin{tabular}{|c|c|c|c|}
\hline Hizmetler (kodlar) & Airbnb & Wimdu & Hemen Kiralık \\
\hline Site tanımı/tarihi & $\bullet$ & $\bullet$ & • \\
\hline Sistemin işleyişi bilgisi & - & $\bullet$ & - \\
\hline Kullanım şartları & $\bullet$ & $\bullet$ & - \\
\hline Politikalar & $\begin{array}{r}\text { Misafir para iadesi politikasıl } \\
\text { ptal politikası }\end{array}$ & $\begin{array}{l}\text { Iptal politikası } \\
\text { Kalite politikası }\end{array}$ & Gizlilik politikası \\
\hline Standartlar & $\begin{array}{r}\text { Konukseverlik } \\
\text { Sorumlu ev sahipliği } \\
\text { Referanslar }\end{array}$ & $\bullet$ & • \\
\hline Garanti & $\begin{array}{r}\text { Ev sahibi garantisi } \\
(1.600 .000 \mathrm{TL}) \\
\text { Afet yardımı }\end{array}$ & $\bullet$ & \\
\hline Rezervasyon & Anında rezervasyon & • & Anında rezervasyon \\
\hline Ödeme seçenekleri & Pay pal/Kredi kart & Pay pal/Kredi kart & $\begin{array}{l}\text { Pay pal/Kredi kartı } \\
\text { Taksit seçeneği }\end{array}$ \\
\hline Koşullar ve Gizlilik & - & $\bullet$ & - \\
\hline Arama filtresi & $\begin{array}{r}\text { Konaklama yeri/türü/tarihi } \\
\text { Fiyat } \\
\text { Konum }\end{array}$ & $\begin{array}{r}\text { Konaklama yeri/türü/tarihi } \\
\text { Fiyat } \\
\text { Konum }\end{array}$ & $\begin{array}{r}\text { Konaklama yeri/türü/tarihi } \\
\text { Fiyat } \\
\text { Konum }\end{array}$ \\
\hline Fotoğraflar & - & $\bullet$ & • \\
\hline Kullanıc Yorumları & $\bullet$ & $\bullet$ & \\
\hline Basında yer alan haberler & $\bullet$ & $\bullet$ & $\bullet$ \\
\hline Mobil desteği & - & & - \\
\hline Güvenlik & $\begin{array}{r}\text { Doğrulanmış kimlik } \\
\text { Ev güvenliği } \\
\text { Kiracı güvenliği }\end{array}$ & • & Doğrulanmış kimlik \\
\hline Sıkça sorulan sorular & • & • & - \\
\hline Dil seçenekleri & 26 dil seçeneği & 15 dil seçeneği & - \\
\hline Sosyal medya bağlantısı & $\bullet$ & • & \\
\hline Yardım merkezi & $\bullet$ & $\bullet$ & • \\
\hline Kullanışılık & • & - & • \\
\hline Fatura & e-posta olarak geliyor & & \\
\hline Iletişim & - & $\bullet$ & - \\
\hline Ev sahibi değerlendirmeleri & Süper ev sahibi & $\bullet$ & \\
\hline Topluluk buluşmaları & $\bullet$ & & \\
\hline Bildirimler & • & & \\
\hline Sorun giderme & • & & \\
\hline
\end{tabular}

Kaynak: https://www.airbnb.com.tr/; http://www.wimdu.com.tr/; https://www.hemenkiralik.com/, 24.12.2014.

deniz fenerleri, yer altı evleri ve ünlü yazarların evleri gibi temalara ayrılmış ve bir görsellik oluşturularak evlere daha rahat erişim sağlanmıştır.

Bu hizmetlerden, alternatif konaklama hizmeti sunan bu sitelerin geleneksel konaklama işletmelerine karşı rekabet sağlamak için sürekli kendini yenilediği ve kullanıcılarına yeni olanaklar sundukları sonucu da ortaya çıkmaktadır. Örneğin, rezervasyon konusuna bakıldığında ev sahibi ve misafir yazışmaları geleneksel konaklama işletmelerindeki rezervasyondan daha fazla zaman ve çaba gerektirmektedir. İncelenen bu üç sitenin 
Tablo 10. Günlük Kiralık Ev Sitelerine Yönelik İstatistiki Veriler (yaklaşık)

\begin{tabular}{|c|c|c|c|c|c|c|}
\hline Site & Ülke (+) & Şehir (+) & Ev sahibi (+) & Misafir (+) & Kayıtı Yer (+) & Kayıtlı kullanicı (+) \\
\hline Airbnb & 190 & 34.000 & 350.000 & 25.000 .000 & 1.000 .000 & \\
\hline Wimdu & 150 & & & & 300.000 & 100.000 .000 \\
\hline Hemen Kiralık & 69 & 643 & & & 27.937 & \\
\hline
\end{tabular}

Kaynak: https://www.airbnb.com.tr/; http://www.wimdu.com.tr/; https://www.hemenkiralik.com/, 24.12.2014.

ikisinde ise (Airbnb ve Hemen Kiralık) bu dezavantajın etkisinin ortadan kaldırmak için "anında rezervasyon" özelliği getirildiği görülmüştür.

\section{Günlük Kiralık Ev Siteleri Kullanıcıları}

Günlük kiralık sitelerinin, Türkiye'nin de dahil olduğu dünyanın birçok ülkesinden kullanıcıları bulunmaktadır. İncelenen sitelerde, genel verilerin yaklaşık olarak verilmesinin dışında kesin istatistiki verilere ilişkin bilgi paylaşımı olmadığı görülmüştür (Bkz. Tablo 10).

2008 yılında kurulan Airbnb'nin 2012 verilerine bakıldığında; 8,5 milyon misafiri ve yarım milyon kayıtlı evi bulunuyorken bu sayı bugün 25 milyon misafir ve bir milyon kayıtlı eve ulaşmıştır. Bu oranlar her gün artmaya devam etmekte ayrıca ülke ekonomilerine de doğrudan ve dolaylı olarak katkı da sağlamaktadır [Örneğin;
Airbnb, 2013 yılında Paris şehrine 185 milyon Avro katkı sağlamıştır (www.airbnb.com.tr, 2015)].

\section{Günlük Kiralık Ev Sitelerinin Tercih Nedenleri}

İncelenen sitelerdeki kiralık evlerin, özellikle büyükşehirlerin merkezi bölgelerinde yaygın olarak hizmet verdikleri görülmüştür. Sitelerin "çevrelerinde bulunan otellerden daha az ücret talep etmelerini" önerdiği bu günlük kiralamalar, normal kiralamalara göre hem daha fazla gelir getirmekte hem de daha az prosedür içermektedir. Bu durum ev sahipleri için avantajlı olduğu kadar kısa süreli konaklama ihtiyacı olan kirac1lar için de oldukça avantajlıdır.

Günlük kiralamaların hem ev sahipleri hem de kiracılar için avantajlı olması bu tür kiralamalara olan talebin artmasına neden olmaktadır. Artan talep ve yüksek getiri beraberinde günlük kira-

Tablo 11. Günlük Kiralık Ev Sitelerinin Tercih Nedenleri

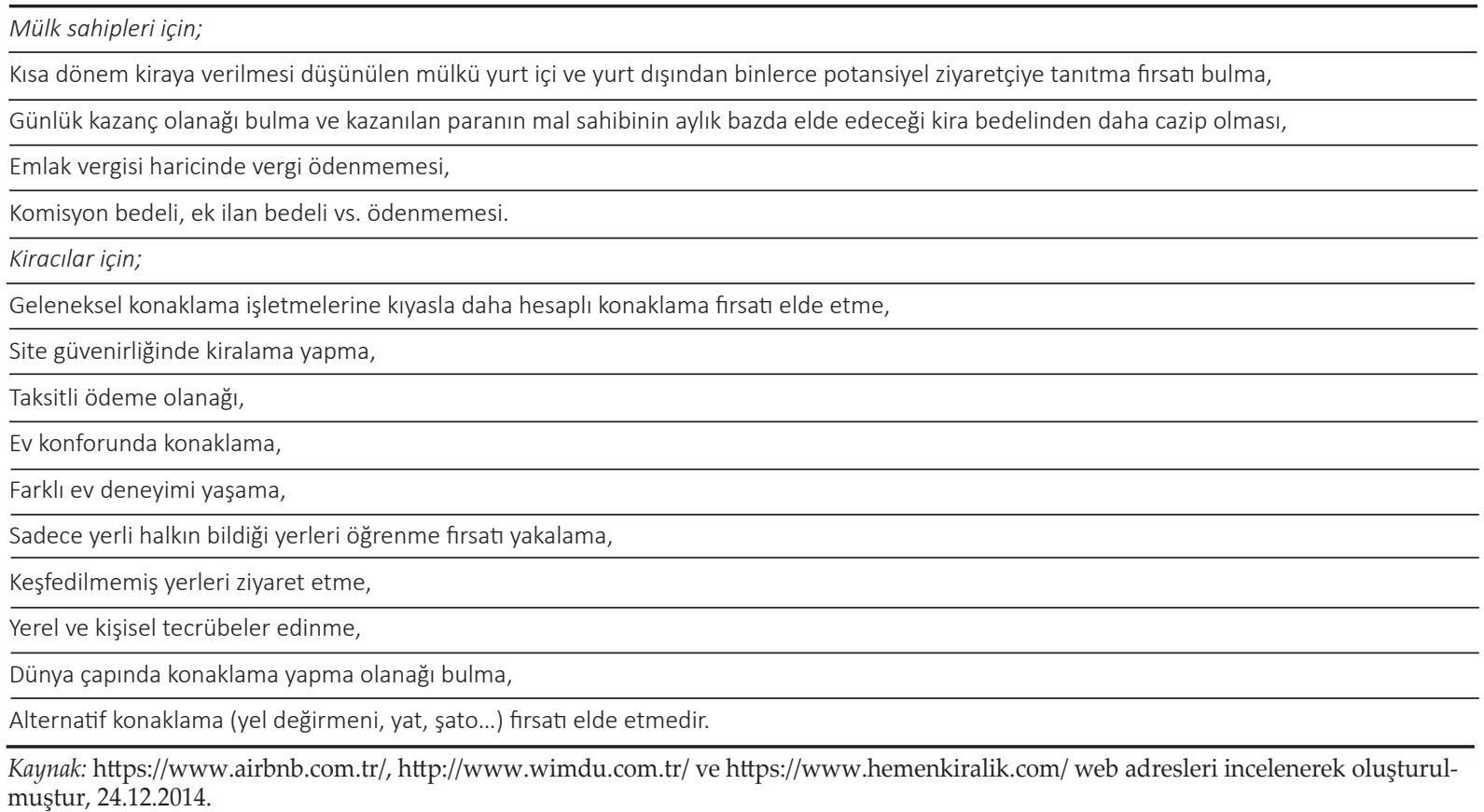

Cilt 27 • Sayı 1 • Bahar 2016 
lamaların sayısında kısa sürede büyük bir artış getirmiş, kişileri güvenli bir sistemde evlerini kiralamaya ve kiracı olmaya yöneltmiştir. Aşağıda Airbnb, Wimdu ve Hemen Kiralık sitelerinin tercih nedenleri tablo şeklinde (Bkz. Tablo 11) verilmiştir.

\section{Günlük Kiralık Ev Sitelerinin Güven Oluşturma Yaklaşımları}

Tüketicilerin risk algılama düzeylerinin satın alma davranışlarında belirleyici rol oynaması güven kavramının pazarlamada ne kadar önemli bir etken olduğunu göstermektedir. Bu çalışma sonucunda ise günlük kiralık ev olanağı sunan Airbnb, Wimdu ve Hemen Kiralık sitelerinin, kullanıcılarında güvensizlik duygusu oluşturmamak için bir takım hizmetler sundukları ortaya çıkmıştır. Bunlar;

- Farklı dillerde hizmet vermeleri,

- Kullanıcılarının kişisel bilgilerini şifreleyerek güvenli hizmet sunmaları,

- Kişisel profiller ve kayıtlar için doğrulama almaları ("Doğrulanmış kimlik" ibaresi),

- Ev sahibi ve misafirlerin tecrübelerinin yorum olarak sitede yayınlanması,

- Kişi profil ve değerlendirmelerinin bulunması,

- Evlerin fotoğraflarının, site fotoğrafçıları tarafından çekilmesi,

- Güvenli ödeme sistemi: Çok sayıda para birimiyle ödeme yapabilme ve alma, misafirlerin kayıt için rezervasyon yaptıklarında site aracılığıyla ödemenin yapılması vs.,

- Faturalarin e-posta olarak gelmesi,

- "Ev sahibi garantisi" uygulaması olması,

- Misafir para iadesi politikası'dır.

\section{Günlük Kiralık Ev Uygulamasının Riskleri}

Lieber (2011) çalışmasında, günlük kiralık ev olanağ1 sağlayan Airbnb'nin New York'taki uygulamasını test etmiş ve hem gürültü hem de temizlik sorunları olduğunu ortaya çıkarmıştır. $\mathrm{Bu}$ araştırma kapsamında incelenen Airbnb, Wimdu ve Hemen Kiralık sitelerindeki kullanıcı yorumlarından çıkan sonuçlar da Lieber'in çalışmasını destekler niteliktedir.
Araştırmada kullanıcıların günlük ev kiralama uygulamasına yönelik algıladıkları riskler şu şekildedir:

- Hijyen,

- Site içerisindeki yorumlar,

- Kişisel güvenlik,

- Gürültü,

- Sorunların nasıl çözüleceği,

- Ev sahipleri,

- Uygunluk takvimlerinin güncellenmemesi.

Günlük Ev Kiralama Uygulamalarının Geleneksel Konaklama İşletmeleri Üzerindeki Etkileri

Kısa süreli konaklama yapacak kişilerin fiyat açısindan dezavantajlı olan otelleri tercih etmeyerek günlük konut kiralamaya yönelmesi şüphesiz otelcilik sektörünü de olumsuz etkilemektedir. Normal şartlar altında otelde konaklayacak bir aile günlük kiralık ev tutarak otele ödeyeceği fazla paradan tasarruf sağlarken diğer yandan otellerin elde edeceği geliri, günlük kiralama faaliyeti ile iştigal eden kimseler elde etmektedir.

Günlük kiralık dairelerin sayısı göz önünde bulundurulduğunda otelcilik sektörünün yaşadığı bu gelir kaybı yüksek meblağlara ulaşmaktadır. Ayrıca günlük kiralık evlerde geceleme ücretlerinin otellere kıyasla daha düşük olması nedeniyle oteller günlük kiralık dairelerle rekabet edemeyecek duruma gelmekte ve buna bağl1 olarak otellerdeki doluluk oranı da düşmektedir. Özellikle kısa dönemli konaklamalarda bu sayı daha da artmaktadır. Örneğin, Airbnb 2012 yılından beri bazı şehirler üzerindeki ekonomik etkisini değerlendiren verileri kendi bloğunda yayınlamaktadır. Bu blogda şimdiye dek dokuz şehre (San Francisco, New York, Paris, Amsterdam, Berlin, Londra, Edinburgh, Sydney, Barcelona) ilişkin veriler otellerle kıyaslandırılarak değerlendirilmiştir. Ziyaretçiler New York'taki otellerde 3,9 gün geceleme yapıp, 690 ABD Doları harcarken, Airbnb ile konaklayanlar New York'ta 6,4 gün kalmakta ve $880 \mathrm{ABD}$ Doları harcamaktadır. Berlin'de ise ortalama 2,3 gece konaklama ve 471 Avro harcama gerçekleştiren ziyaretçiler, Airbnb ile gerçekleştirdikleri Berlin ziyaretinde 6,3 gece konaklama yapmakta ve 845 Avro harcamaktadır (blog.airbnb.com 2015). 
Geleneksel konaklama işletmelerini olumsuz etkileyen sebeplerden bir diğeri de konaklama işletmelerinin genellikle sadece turistik bölgelerde yoğunlaşması, günlük kiralanan evlerin ise her yerde ve çok sayıda bulunabilmesidir. Son dönemde rezidans dairelerin de günlük kiralık sektörüne katılmasıyla birlikte kalite, konfor, temizlik ve güven bakımından otel seviyesinde, rahatlık olarak da otellerden daha rahat konaklama olanakları ortaya çıkmıştır. Bu noktada bir konaklama işletmesinden beklenen hemen hemen tüm hizmetler günlük kiralık evlerde verilmektedir (Erdoğan, 2013).

Türkiye'de ise günlük kiralama faaliyetlerinin yasası veya düzenlemesi bulunmadığından gün geçtikçe daha fazla yaygınlaşmaya başlayan günlük kiralık yatak sayısı sadece İstanbul'da 20 bini bulmuştur. Türkiye İstatistik Kurumu'nun yayınladığ 12012 turizm verileri alternatif konaklama sektörünün Türkiye'de de büyüdügünü göstermektedir. Verilere göre Türkiye'de yapılan konaklamaların yaklaşık yüzde dört ila beş oranındaki kısmı kiralık evlerde yapılmaktadır. Fiyatları 80 TL ile 500 TL arasında değişen bu evlerde, 2012 yılında İstanbul'daki gecelemelerin sekiz milyonu gerçekleştirilmiştir (turizmaktuel. com, 2015).

\section{SONUÇ VE ÖNERILER}

Bu çalışmada resmi olmayan konaklama sektöründeki değiş-tokuş ve günlük kiralık ev trendinin geleneksel konaklama sektörü üzerindeki etkilerinin belirlenmesine yönelik bilgilere ulaşılmaya çalışılmıştır. Dünya genelinde alternatif konaklama olanağı sunan bu sitelerden altı tanesi (Home Exchange, Home Link, Love Home Swap, Airbnb, Wimdu, Hemen Kiralık) amacı, hizmetleri, kullanıcı sayıları, tercih nedenleri, nasil güven verdikleri, riskleri doğrultusunda incelenmiştir. Bu incelemelerde değiş-tokuş ve kiralık uygulaması sunan sitelerin gün geçtikçe büyüdüğü ve otel işletmeleri için, şu an sınırlı olsa da bir tehdit oluşturduğu ortaya çıkmıştır.

Sitelerin temel amaçları; daha fazla kişiye ulaşarak tüm dünyaya seyahat gerçekleştirme olanağı sağlamak, yerel ekonominin kalkındırılma- sına katkıda bulunmak, aynı fikirleri paylaşan insanları bir araya getirmek, yeni yer ve kültürlerin keşfedilmesini sağlamaktır. Bu amaçlar doğrultusunda her site daha fazla kullanıcı çekmek adına kendince güven oluşturacak hizmetler sunmaktadır. Web sitesi ve kullanıcı arasında güven oluşturan bu hizmetlerin en önemlileri ise daha önce konaklama yapan kullanıcıların tecrübelerinin değiştirip engellenmeden sitede yorum olarak yayınlanması, kullanıcıların kişisel bilgilerinin şifrelenmesi ve birçok konuda garanti sağlanmasıdır. Güven yaratmak siteler için en önemli unsurdur, çünkü insanlar güvenmedikleri hiçbir şeyi tercih etmezler.

Çalışmada ayrıca değiş-tokuş ve günlük kiralama yapmak isteyen web kullanıcılarının sitelerde aradıkları bilgiye olabildiğince hızlı bir şekilde ulaşabildiği görülmüştür. Bu da incelenen web sitelerinin etkin bir şekilde çalıştığının bir göstergesidir. Web sitelerinin dinamik bir yapısı olduğu düşünüldüğünde sayfaların kullanıcı merkezli yapılandırılması ve düzenli olarak güncellenmesi gerektiği ortaya çıkmaktadır.

Sitelerin tercih nedenlerine bakıldığında ise maliyet tasarrufu sağlamak, ev rahatlığında yerli gibi tatil yapmak, başka ailelerin yaşamını deneyimlemek gibi etkenler olduğu görülmüştür. Ayrıca bu siteleri tercih eden kişilerin daha çok eğlence amacıyla seyahat eden kişiler oldukları ortaya çıkmıştır. Buradan iş amaçlı seyahat eden kesimin bu siteleri çok fazla tercih etmediği kurumsal seyahat politikası, sadakat programları, hizmet standartları gibi nedenlerle otellere sadık kaldıkları öngörülebilmektedir.

Değiş tokuş ve günlük kiralık ev bulma olanağ sağlayan sitelerin devamlı bir büyüme göstermesi günümüzde geleneksel konaklama işletmeleri üzerinde bir endişe yaratmıştır. Tatillerini geleneksel konaklama işletmelerinde geçiren insanları sunduğu hizmetlerle kendine çekerek paylaşım ekonomisine yöneltmiş ve otelleri dezavantajlı bir konuma getirmiştir.

Avrupa'da uzun yillardır var olan bu uygulamalar Türkiye'de yeni faaliyet gösteren bir sektör olarak göze çarpmaktadır. Bu konuda Türkiye'de hiçbir yasal düzenlemenin bulunmaması ise sıra- 
dan insanları profesyonel bir otelciğe dönüştürmektedir. Ayrica oteller belirli kanunlara, vergi denetimine tabi olurken değiş tokuş ve günlük ev kiralamada böyle bir durumun olmaması, ciddi oranda bir vergi kaybını da beraberinde getirmektedir.

Beklentilerin arttığ 1 ve teknolojinin tüketiciye her an daha farklı seçenekler sunduğu bir atmosferde konaklama işletmeleri, var olan bu talepleri göz ardı etmemeli konaklamaları daha ilginç ve özgün hale getirmenin yollarını bulmaya çalışmalıdır. Bunu gerçekleştirmediği taktirde şu an bir niş pazar durumunda olan bu sektör daha da büyüyecek konaklama işletmeleri üzerinde gerçek anlamda bir tehdit olacaktır.

Araştırmanın bu haliyle, değiş-tokuş ve günlük ev kiralama olanağı sağlayan sitelerin; tercih nedenlerini, hizmetlerini ve risklerini belirleyen bir araştırma olması, gelecekte yine aynı alanda yapılacak diğer çalışmalara 1şık tutabilmesi açısından bir ön çalışma niteliğindedir. Gelecekte, bu sitelerin etkilediği düşünülen otel işletmeleriyle görüşmeler yapılarak, bu çalışmada ortaya çıkan sonuçlara yani sitelerin sundukları olanaklara karşı nasıl bir rekabet geliştirdikleri belirlenebilir ve ayrıca otelleri ne oranda etkilediklerine yönelik sayısal verilere de ulaşılabilir.

\section{KAYNAKÇA}

Airbnb (2015). Airbnb Economic Impact. http://blog.airbnb. com/economic-impact-airbnb/, Erişim tarihi: 25 Temmuz 2015.

Akın, B. (2013). Ev Kiralama ve Ev Değişimi. https://burakakin. wordpress.com/2013/02/02/kisa-sureli-ev-kiralama-ve-evdegisimil, Erişim tarihi: 21 Temmuz 2015.

Arente, H. ve Kiiski, V. (2006). Tourist Identity Expression through Postmodern Consumption - A Focus on the Home-Exchange Phenomenon Yüksek Lisans Tezi, No 2005: 78. Göteborg: Göteborg Üniversitesi.

Best, J. (1959). Research in Education. New Jersey: Prentice Hall.

Bilgin, N. (2006). Sosyal Bilimlerde İçerik Analizi. Teknikler ve Örnek Çalışmalar. Ankara: Siyasal Kitabevi.

Black, J. (1985). The British and The Grand Tour. New York, NY: Routledge.

Botsman, R. ve Rogers, R. (2010). What's Mine is Yours: The Rise of Collaborative Consumption. New York: HarperCollins.

Cevheroğlu, E. (2011). Freecycle: Kullanmadığınız Eşyaları Değerlendirin!, http://www.yesilplatform.com/2011/07/28/ freecycle-kullanmadiginiz-esyalari-hediye-ederek-dunyayidegistirin/, Erişim tarihi: 22 Aralık 2014.
Christensen, C. M. ve Raynor, M. E. (2003). The Innovator's Solution: Creating And Sustaining Successful Growth. Boston, MA: Harvard Business School Yayınları.

Cohen, L., Manion, L. ve Morrison, K. (2007). Research Methods in Education. 6. Bask1, New York, NY: Routledge.

Dalgın, T. ve Karadağ, L. (2013). Restoran İşletmeleri Web Sitelerinin İçerik Analizi: Marmaris-Bodrum Örneği, AIBÜ Sosyal Bilimler Enstitüsü Dergisi, 13 (2): 133-150.

Duverger, M. (1973). Sosyal Bilimlere Giriş: Metodoloji Açısından. Çeviren: Ünsal Oskay. Ankara: Bilgi Yayınevi.

Edelman, B. G. ve Luca, M. (2014). Digital Discrimination: The Case of Airbnb.com. Harvard Business School NOM Unit Working Paper, No. 14-054.

Erdoğan, E. (2013). Bireyler Arası Paylaşım Platformu Kiraguru.com. https://erdmerdgn.wordpress.com/, Erişim tarihi: 25 Temmuz 2015.

Finley, K. (2013). Trust in the Sharing Economy: An Exploratory Study. http://www2.warwick.ac.uk/fac/arts/theatre_s/ cp/research/publications/madiss/ccps_a4_ma_gmc_kf_3.pdf, Erişim tarihi: 19 Aralık 2014.

Forno, F. ve Garibaldi, R. (2013) My House is Yours: A Worldwide Study on Home Exchangers' Profiles and Motivations. University of Bergamo. http://homeex-ux. s3.amazonaws.com/affinities/1/pdf/homeexchange_bergamo_study_2013_EN.pdf, Erişim Tarihi: 22 Aralık 2014.

Gansky, L. (2010). The Mesh: Why the Future of Business is Sharing. New York: Penguin Group.

Gökçe, O. (2006). İçerik Analizi, Kuramsal ve Pratik Bilgiler.İstanbul: Siyasal Kitabevi.

Grant, M. (2013). Airbnb.com Poses Only A Small Threat To Hotel Industry. Euromonitor International, $h t t p: / / b l o g$. euromonitor.com/2013/03/airbnbcom-poses-only-a-smallthreat-to-hotel-industry.html, Erişim tarihi: 22 Aralık 2014.

Grit, A. (2008). An Analysis of the Development of Home Exchange Organizations. Paper presented at the 26th EuroCHRIE conference, 11-14 Ekim, Dubai.

Groote, P. ve Nicasi, F. (1994). Home Exchange: An Alternative Form of Tourism and Case Study of the Belgian Market, Tourism Review, 49 (1): 22-26.

Guttentag, D. (2015). Airbnb: Disruptive Innovation And The Rise Of An Informal Tourism Accommodation Sector, Current Issues in Tourism, 18 (12):1192-1217.

https://www.homeexchange.com/tr/, Erişim tarihi:15 Aralık 2014-20 Aralık 2014-21 Aralık 2014.

http://www.lovehomeswap.com/, Erişim tarihi: 15 Aralık 2014-20 Aralık 2014-21 Aralık.2014.

http://homelink.org/tr/, Erişim tarihi: 15 Aralık 2014-20 Aralık 2014-21 Aralık 2014.

https://www.airbnb.com.tr/, Erişim tarihi: 15 Aralık 2014-24 Aralık 2014.

http://www.hemenkiralik.com/, Erişim tarihi: 15 Aralık 2014-24 Aralık 2014.

http://www.wimdu.com.tr/, Erişim tarihi: 15 Aralık 2014-24 Aralık 2014.

Kurtz, M. (2014). In Focus: Airbnb's Inroads Into the Hotel Industry. HVS. HVS Houston, 1 June. http://www.hospitalitynet.org/file/152005413.pdf, Erişim tarihi: 21.12.2014. 
Kurulgan, M. ve Bayram, F. (2006). Üniversite Kütüphaneleri Web Sitelerinin Biçim ve İçerik Analizi: Türkiye'deki Uygulamaya İlişkin Bir Araştırma, Refereed Papers Türk Kütüphaneciliği, 20 (2): 141-172.

Lieber, R. (2011). Airbnb's Lodging Gets Tested, Yielding A Mixed Bag. The New York Times, http://www.nytimes. com/2011/11/12/your-money/airbnb-gets-five-night-test-innew-york-city.html?pagewanted=all, Erişim tarihi: 20 Aralik 2014.

Marangoz, M., Yeşildağ, B. ve Saltık Arıkan, B. (2012). E-Ticaret İşletmeleri Web ve Sosyal A $\breve{g}$ Sitelerinin İçerik Analizi Yöntemiyle İncelenmesi, Internet Uygulamaları ve Yönetim Dergisi, 3 (2): 53-78.

Mayock, P. (2013). Peer-to-Peer Booking Sites No Threat To Demand. HotelNewsNow, http://www.hotelnewsnow. com/Articles.aspx/10511/Peer-to-peer-booking-sitesnothreat-to-share, Erişim tarihi: 19 Aralık 2014.

Mayring, P. (2000). Nitel Sosyal Araştırmaya Giriş. Çeviren: A. Gümüş ve M. S. Durgun, Adana: Baki Kitabevi.

Özbaran, M. H. (2012). Ev Değiş-Tokuş Sistemi Nedir Ne Değildir?, http://www.gezialemi.com/HaberAyrinti. asp?ID=639ESAYFA=4, Erişim tarihi: 23 Aralık 2014.

Rummel, J. F. (1964). An Introduction to Research Procedures in Education. 2. Bask1. New York: Harper and Row.

Silverman, D. (2005). Doing Qualitative Research. Londra: Sage.

Sinka, M. P. ve Corne, D. W. (2004). Measuring Effectiveness Of Text-Decorated HTML Tags in Web Document
Clustering. IADIS International Conference on Cognition and Exploratory Learning in Digital Age, Murcia, İspanya.

Scott, D. ve Morrison, M. (2005). Key Ideas in Educational Research. Londra: Continuum International Publishing.

Shankland, S. (2013). Airbnb Founder: Banning Private Rentals As Silly As Banning Cars. CNET, http://news. cnet.com/8301-1023_3-57587754-93/airbnb-founderbanningprivate-rentals-as-silly-as-banning-cars/, Erişim tarihi: 20 Aralık 2014.

Tosuner, A. (2011). Ortak Kullanım Ağları (Collaborative Consumption Networks): Hiper Tüketimden Paylaşımc1 Kullanıma, http://zumbara.wordpress.com/tag/aslitosunerl, Erişim tarihi: 23 Aralık 2014.

Tosuner, A. (2012). Tüketim Davranışının Azaltılması İçin İnternetin Kullanılması: Ortak Kullanım Ağları, 17. Internet Konferansı, Anadolu Üniversitesi, Eskişehir, Türkiye, 7 Kasim 2012.

Turizm Aktüel (2013). Kiralık Ev Furyası. http://turizmaktuel. com/assets/2013-7.pdf, Erişim tarihi: 25 Temmuz 2015.

Walsh, B. (2011). 10 Ideas That Will Change The World. TIME. http://www.time.com/time/specials/packages/article/0,28804,2059521_2059717,00.html/. Erişim tarihi: 23 Aralık 2014.

World Economic Forum (2013). Position Paper: Young Global Leaders Sharing Economy Working Group. World Economic Forum Young Global Leaders Taskforce: Cir-
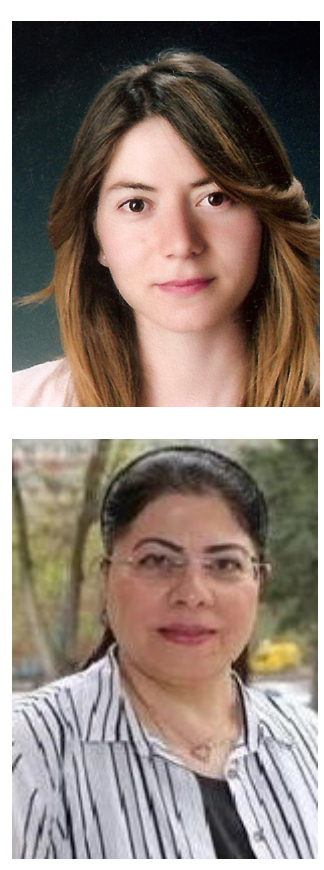

Dilek DEMIRER

Düzce Üniversitesi Akçakoca Turizm İșletmeciliği ve Otelcilik Yüksekokulu'ndan mezun oldu (2010). Yüksek lisans derecesini Düzce Üniversitesi'nden Turizm ve Otel İşletmeciliği Anabilim dalından aldı (2015). Temel çalışma alanları turizm pazarlaması, kültürel miras, alternatif turizm, edebiyat turizmidir.

\section{Prof. Dr. Azize HASSAN}

Gazi Üniversitesi Meslek Eğitim Fakültesi Turizm İşletmeciliği ve Otelcilik Bölümü'nden mezun oldu (1985). Gazi Üniversitesi Ticaret ve Turizm Eğitim Fakültesi Turizm İşletmeciliği Eğitimi Bölümü'nde araştırma görevlisi olarak göreve bașladı (1987). Yüksek lisans derecesini Gazi Üniversitesi'nden Üretim Yönetimi ve Pazarlama dalından (1989), doktora derecesini de i̇stanbul Üniversitesi'nden Turizm dalından aldı (1993). Gazi Üniversitesi Ticaret ve Turizm Eğitim Fakültesi'ne doçent olarak atandı (1999). Gazi Üniversitesi Ticaret Turizm Eğitim Fakültesi'nde profesörlüğe yükseltildi (2004). Halen Gazi Üniversitesi Turizm Fakültesi, Turizm İşletmeciliği Bölümü'nde öğretim üyesi olarak görev yapmaktadır. Temel çalıșma alanları genel turizm, turizm ve turizm işletmelerinde pazarlama alanına giren konulardır. 